\title{
Narratives on the Beginning of the 1875-1878 Uprising in Bosnia and Herzegovina in the British Public Discourse*
}

\author{
EDIN RADUŠIĆ** \\ Faculty of Philosophy, University of Sarajevo
}

\begin{abstract}
In his noteworthy book Against Massacre, Humanitarian Interventions in the Ottoman Empire 1815-1914 (2012), Davide Rodogno states that even prior to the Eastern Crisis (1875-1878), the Ottoman Empire and Turks had been excluded from civilised states and nations for several reasons (despotism, Islam, polygamy, slavery, impossibility of reformation). Thereby, the Europeans have secured the position of being the only ones determining the standards of civilisation: they decide how, where and when a nonEuropean country will access the family of civilised people. As a supplementary part of orientalism, balkanism and ottomanism, as well as a justification to the implementation of the "western" double standard, it was stereotypical to construct a negative image of Turks that also included Muslims from Bosnia and Herzegovina. In the period of crisis, such was the 1875-1878 Eastern Crisis, the British and other European public and political elite, including Russia, had developed considerable anti-Turkish sentiments. In this paper, I analysed and synthesised discourses about Bosnia and Herzegovina in the British public space, from the beginning of the uprising in 1875, to the anti-Turkish campaign following the Turkish crimes in Bulgaria in May 1876. The discourse on the uprising of the British Consulate in Bosnia and the anti-Ottoman discourse of the British press in relation to the uprising in Bosnia and Herzegovina appeared as especially important. The last one appeared through several narratives: oppression as a way of rule, oppression as the cause of the uprising, oppression and the Turkish crimes over Christians as an argument for a humanitarian intervention and western (Austrian) occupational right.
\end{abstract}

Key words: Bosnia and Herzegovina, 1875-1878 uprising in Bosnia and Herzegovina, Great Britain, Muslims, Christians, “Turks”, William Holmes, The Times, Daily News, The Pall Mall Gazette.

\footnotetext{
* This paper is an excerpt from the author's book "Bosnian Horrors": antiturski narativi o Bosni u britanskom javnom diskursu i njihove političke posljedice 1875-1878., (Studije za historiju BiH, book 5). Sarajevo: Udruženje za modernu historiju, 2019.

"PhD. History Department. Email address: edin.radusic@ff.unsa.ba
} 


\section{Consular Discourse on the Uprising in Bosnia and Herzegovina (until the beginning of the Anti-Turkish "Atrocities Agitation")}

When the news of the unrest in East Herzegovina spread in July 1875, the great powers did not take a special interest and did not undertake any significant activities. Due to a large number of refugees in their territories, as well as the agitation that had appeared among the Austrian Slavs in Croatia, Austro-Hungary was the first to react. Apart from that, a political wing that advocated the military occupation of Bosnia and Herzegovina as the most secure means against the dangerous Yugoslav movement was active in Vienna. In Russia, there was a difference between solidarity of the public with the kindred population of Bosnia and Herzegovina, who also shared the same faith, and the official Petrograd, who, at the time, observed Serbs as the unwanted revolutionaries, and who did not want to go to war due to bad finances and an ill-equipped army. The Foreign Office was informed as early as July 1875 through consular and diplomatic reports about the beginning of unrests, as well as about all other changes in Herzegovina and in Bosnia. Although it was not evident in the beginning, the uprising in Bosnia and Herzegovina had become until the spring of 1877 one of the core issues in the British foreign and, in part, interior politics. Proportionate to the situation in the field and the increased interest of other powers for this issue, the Foreign Office's interest grew as well, including the British Government and the country as a whole. ${ }^{1}$

Upon hearing of the unrest, consul Holmes had a meeting with the vali (gouverneur-général, translator's note), gathered information and informed Ambassador Elliot about the issue on 2 July 1875. That was the onset of activities of the British diplomatic and consular service, as well as the Foreign Office, which was considerably engaged in monitoring the uprising and in attempting to settle it. At the beginning of the uprising, the British Government advocated the policy of non-interference in order to leave space for the Ottoman authorities to end it by a military intervention, but, when that had failed, Great Britain, together with other powers, actively started monitoring the uprising with the aim of pacifying it. The entire British consular activity was twofold. First, the consul and his deputy informed the embassy in Constantinople and the Foreign Office directly about the events in the field, stating their opinion on the causes, duration and consequences of the uprising against the British interests. In the process of assembling information, they communicated with the Ottoman authority representatives and military commanders in the field, representatives of other consular powers and other players in the crisis. Second, the British consul in Sarajevo and the ambassador in Constantinople, separately or in correlation with other consuls and ambassadors, participated in the field, finding a solution for the crisis caused by the uprising, as

${ }^{1}$ Radušić 2013, 256. 
well as for the Eastern Crisis as such, while the Foreign Office also did that at the highest level, through the system of negotiations and agreement with other major powers, in an attempt to directly influence the Sultan and the Sublime Porte. It should also be mentioned that, among all the politics of major powers, the British politics was most positively perceived by $\mathrm{BiH}$ provincial and central Ottoman authorities, and, consequently, most negatively by the rebels and their supporters.

An official interpretation of the systematic and immediate causes and goals of the uprising, its duration, parties involved and their mutual relations, as well as the relationship among the Slavic population - Muslims and Christians, reflections of the uprising to the relations among great powers, and, finally, proposals for the main course of the British politics regarding the issue in the field, was created by the longserving British consul in Bosnia, William Richard Holmes (January 1860 - June 1877). ${ }^{2}$ He was an adherent of the Disraeli's eastern politics of the preservation of sovereignty and integrity of the Ottoman Empire, while the political opponents and later authors called him a Turcophile. The image of the beginning of the uprising Holmes created shows that the uprising was initiated and maintained from the outside (from Serbia and Russia). According to him, there had been no significant cause for the rebellion. There were no instances of violence escalation or systematic oppression, and the situation in that regard was not worse than in the period after $1860 .{ }^{3}$ Violence, he interpreted, was a side-effect of the uprising, and was perpetrated by both the conflicting parties, but more by the rebels against the domicile Muslim population. ${ }^{4}$ The rebels used force to spread the base of the uprising and increase the number of participants. They also killed Christians and perpetrated other forms of crime over those who refused to join them and who had remained loyal to the Ottoman authorities. According to him, the main problem were the aspirations and the propaganda of Serbia, Montenegro, Russia and a part of the Austro-Hungarian Monarchy, who used Christians from Bosnia and Herzegovina to implement them. Also, Holmes did not deny the difficult economic position of the Christian population and issues in the implementation of reforms, as well as individual cases of Islamic fanaticism. He was of the opinion that the goal of the uprising was not the liberation of from the Ottoman rule, but to correct the injustices at the local level and to improve their social and economic position. ${ }^{5}$

\footnotetext{
${ }^{2}$ Radušić 2013, 76-77.

${ }^{3}$ In the decades preceding the uprising, Holmes would send reports testifying cooperation and neighbourly relations between the local Muslims and Christians. See: Radušić, 2014, 97-113.

${ }^{4}$ On September 30, 1876 Holmes reported about the horrific crimes of the uprisers in Nevesinje, stating to have personally witnessed a boy with head decapitated and a slaughtered young woman. Holems-Derby, Mostar, September 20, 1875, Turkey, No. 1, 1876, 27.

${ }^{5}$ Memorandum by consul Holmes regarding the Affairs of the Herzegovina, Enclosure in no. 67, in Elliot-Derby, Constantinople, March 10, 1876, Turkey, No. 3 (1876), no. 67, 39-41. and DerbyElliot, Foreign Office, March 30, 1876, Turkey, No. 3 (1876), no. 94, 53.
} 
Holmes' interpretation of the cause, the beginning and the maintenance of the uprising was fully accepted by the British Embassy in Constantinople and the London Cabinet, ${ }^{6}$ although certain circles of the English society were sceptical regarding the accuracy of the perception of the diplomats and consuls who had long served in the Ottoman Empire. ${ }^{7} \mathrm{He}$ advocated further support to the Ottoman reform attempts of equalising all subjects of the Ottoman Sultan, of improving the position of all people in Bosnia and Herzegovina and its preservation within the Ottoman Empire. ${ }^{8}$ An analysis of their key positions regarding a wide spectre of issues related to the uprising in Bosnia and Herzegovina shows that he was inclining towards the attitudes of reforms advocated by a part of the Ottoman elite towards the western orientalist discourse. He too was of the opinion that there had been exterior causes of the uprising, and he minimised the internal economic and social causes of dissatisfaction of a part of the local population. His prevailing opinion was that the Ottoman Empire and all loyal citizens, especially Muslims, were victims of by far greater violence and injustice than the one they had perpetrated to others. In his discourse, together with the foreign powers and the neighbouring principalities Russia, in part also Austro-Hungary, Montenegro and Serbia, the disloyal Christian subjects of the Empire were the main culprits for the unrest and, consequently, for jeopardising the European peace as the highest value advocated most strongly by Great Britain and other major powers in the public politics.

The British Deputy Consul in Bosnia and Herzegovina, Edward Freeman, observed the events in Bosnia and Herzegovina in the period of the uprising to a certain extent differently, especially regarding the issue of an unequal position of Christians and violence committed over them, as well as the crucial issue, determined

\footnotetext{
${ }^{6}$ See, esp.: Memorandum by Consul Holmes regarding the Affairs of the Herzegovina, Inclosure in no. 67, in Elliot-Derby, Constantinople, March 10, 1876, Turkey, No 3 (1876), no. 67, 39-41. and Derby-Elliot, Foreign Office, March 30, 1876, Turkey, No. 3 (1876), no. 94, 53. Also extensively in: Radušić 2013, 258-59.
}

${ }^{7}$ Iseminger is of the opinion that the British diplomats and consuls were exposed to the temptation of unclear loyalty. He concludes, a bit too freely, and by citing The London Times, that such consuls would become increasingly pro-Turkish, would lose the English identity and, since the British eastern politics was significantly shaped by the information and advice from the consuls, their laps of loyalty would occasionally embarrass the government. Iseminger 1968, 297.

${ }^{8}$ Memorandum by Consul Holmes regarding the Affairs of the Herzegovina, Enclosure in ElliotDerby, Constantinople, March 10, 1876, Turkey, No. 3 (1876), no. 67, 40; F.O. 195/1101, HolmesElliot, Sarajevo, July 15, 1876, No. 39; Holmes-Derby, Sarajevo, July 25, 1876, Turkey 1 (1877), No. 6, 4; F.O. 195/1101, Holmes-Elliot, Sarajevo, September 13, 1876, No. 51; Holmes-Derby, Sarajevo, September 14, 1876, Turkey No. 1 (1877), No. 391, 309; F.O. 195/1101, Holmes-Elliot, Sarajevo, October 26, 1876; Holmes-Derby, Sarajevo, October 27, 1876, Turkey No. 1 (1877), No. 881, 601-603; Holmes-Derby, Sarajevo, October 12, 1876, Turkey, No. 1 (1877), No. 763, 536; Holmes-Elliot, Mostar, April 20, 1876, Turkey, No 3 (1876), No. 189, 114; Green-Derby, Skadar, October 23, 1876, Turkey, No. 1 (1877), No. 862, 592. See also Radušić 2013, 286-87. 
by the West, concerning the ability of the Ottoman Empire to transform itself into a state of equal rights for all. He was more prone to the Christian population and was suspicious of the possibility of the reformation of the Ottoman Empire, especially after the uprising, when the trust of a large number of the Christian population in the firmans (decrees $-\mathrm{T} / \mathrm{N}$ ) of the sultan and the reform measures was lost. Considering the reform activities by the Ottoman authorities in the period of the uprising that granted more concretely equal rights to all people, E. Freeman stated that the reforms could have had effect in the period of peace and that they could have prevented the uprising, but the expected effect in the period of the unrest was unrealistic, in the sense that they would not ease the situation. He emphasised that the complete equality of the population could not have taken place until a part of the population was eligible to bear weapons, while others were prohibited from doing so. ${ }^{9}$ However, Freeman's systematically weaker position compared to Holmes', as well as Holmes' reputation in the political and diplomatic structures of the conservatives, prevented an equal treatment of Freeman's understanding of the situation with Holmes.

It is important to emphasise that the attitudes and observations presented in William Holmes' reports and, to a lesser extent in those of Edward Freeman, were considered and integrated into the official politics of London in the process of finding a way to pacify the situation in Bosnia and Herzegovina and to solve the Eastern Crisis. Their attitudes were especially influential in the early stages of the uprising and in the first phase of the Eastern Crisis (until the "Bulgarian atrocities", even until the Russo-Turkish war that started 24 April 1877), when Bosnia and Herzegovina held a very high position in the British eastern politics. Holmes' influence in the Foreign Office can be illustrated by the fact that he was part of the British negotiating team at the Constantinople conference and that the instructions for the head of the British team, Lord Salisbury, regarding the issues in Bosnia and Herzegovina, were largely comprised by his reports and observations. The reports made by deputy consul Freeman were used in a lesser extent in the process of comprising the instructions. ${ }^{10}$

${ }^{9}$ F.O. 195/1101, Freeman-Elliot, Sarajevo, February 3, 1876, No. 7, A copy of the decree was sent to the Foreign Office, signed as Consular No. 7; Freeman-Derby, Sarajevo, February 3, 1876, Turkey, No. 3 (1876), No. 9, 5; Freeman-Derby, Sarajevo, February 18, 1876, Turkey, No 3 (1876), No. 24, 10-11; F.O. 195/1101, Freeman-Elliot, Sarajevo, April 21, 1876, No. 20. The same decree was sent to the Foreign Office on that same day, signed as Political, No. 12; E. Radušić 2013, on several places, especially p. 277. Cf. the status of the Balkans in different British political discourses from the mid-1 $19^{\text {th }}$ century to 1914 , as presented by Ana Savic in the introductory session of her dissertation. That section of the dissertation was based on the general literature and published sources. Savic 2008, 14-71.

${ }^{10}$ See: F.O. 195/1101, Holmes-Elliot, Sarajevo, July 15, 1876, No. 39; Holmes-Derby, Sarajevo, July 25, 1876, Turkey 1 (1877), No. 6, 4; F.O. 195/1101, Holmes-Elliot, Sarajevo, September 13, 1876, No. 51; Holmes-Derby, Sarajevo, September 14, 1876, Turkey, No. 1 (1877), No. 391, 309; 


\section{Oppression as a Way of Rule and the Cause of the Uprising}

In the period from the beginning of the uprising in 1875, the English newspapers and public started paying more attention to the events in Bosnia and Herzegovina, and in the Ottoman Balkans as a whole. After the Crimean War, that was the first more serious opportunity for the British public to again take interest in the issue of the Ottoman Empire, its survival and territorial integrity. Indeed, the very nature of events in Bosnia and Herzegovina, as well as the opposing sides in the conflict, with other, new factors in the Eastern Question, had, in advance, prevented an almost unified attitude that had formed during the Crimean War about whom to support and what feeling towards the current issue to express. While, in the Crimean War, the perception of the Russian threat to the primary British imperial and national interests caused the British public to incline towards Russophobia and a forced, ostensible Turcophilia, the open issue of the Ottoman Christian subjects in the Balkans and the perception of their systematic unequal position and oppression by the sultan's authority and the local Muslim population, led England in an opposite direction to that from the Crimean War period. In the period of the 1875-1878 Eastern Crisis, the English press, still, not all and not in the same intensity, created a negative image of the Ottoman Empire and Turks as a whole, including the local Muslim population from Bosnia and Herzegovina and other Slavic Muslims.

I here begin from The Times newspaper narrative and the image it had created regarding the manner in which the Ottomans ruled, their barbaric and criminal character, normative and real position of Christians, and the relationship of the local Muslims towards Christians in Bosnia and in the Balkans, in the Ottoman context. The Times' narrative on the oppression of Christians by the Ottoman rule and by the local Muslim population was created by editorial observations, the selection of information from own sources, or by citing texts from other British and European papers published at the time, as well as by the information and observations of The Times correspondents from the rebel strongholds, surrounding and other political centres of importance for monitoring and possible solving of the crisis. Opening of the Bosnian issue in the public British space made current the older opinions related to the situation in the Eyalet of Bosnia, stemming from the Crimean War period and the subsequent "unreserved support" to the Ottoman Empire, when their mutual relations were undisturbed. ${ }^{11}$ In that sense, in August 1875, The Times

F.O. 195/1101, Holmes-Elliot, Sarajevo, October 26, 1876; Holmes-Derby, Sarajevo, October 27, 1876, Turkey, No. 1 (1877), No. 881, 601-03; Holmes-Derby, Sarajevo, October 12, 1876, Turkey, No. 1 (1877), No. 763, 536; Holmes-Elliot, Mostar, April 20, 1876, Turkey, No 3 (1876), No. 189, 114; Green-Derby, Skadar, October 23, 1876, Turkey, No. 1 (1877), No. 862, 592.

${ }^{11}$ Maria Todorova, in her book Imagining the Balkans, used an example of the creation of an image of the Ottoman Empire in France to show the dependence of the image from the dominant mutual political relations. Todorova 1999, 133-39. 
editor discussed the uprising and stated that it had shown the strength of survival, analysing attitudes presented in Arbuthnot's travelogue published in $1862 .{ }^{12}$ In the context of the new circumstances, the editor critically examined his attitudes and stated that Arbuthnot was on the Muslim side, although, as the commentator emphasised, his assumptions were not unreasonable and extravagant. The editor emphasised that Arbuthnot negated the oppression in Bosnia and Herzegovina, but clearly stated that the Ottoman subjects were exposed to misgovernment, which was the main characteristic of the Ottoman rule. In a continuous, centurieslong misgovernment, The Times editor saw a strong link to the main causes of the uprising of the Christian peasantry in Herzegovina and Bosnia, constructing a strong statement that, in the perception of peasantry, the misgovernment had easily turned into a systematic oppression to which the local, Slavic Muslims from Bosnia and Herzegovina significantly contributed. ${ }^{13}$ In this narrative, Muslims from Bosnia and Herzegovina were even worse than the central Ottoman authority and its representatives in the province. ${ }^{14}$ That phenomenon is especially visible after the failure of Omer Pasha Latas in the 1850s to efficiently implement the reforms and make all population of the province equal in their rights and obligations. The Times editor in this case emphasised a certain allegiance of the local Christians and the central authority against the local Muslim nobility. Others would see the annihilation ofleaders of the resistance to reforms and modernisation of the country, where the former would be freed from oppression of the local Muslim elite in the issues of land..$^{15}$ The responsibility of the authority in this narrative stemmed from

\footnotetext{
12 Arbuthnot 1969 .
}

13 "Nor do we see how the former is much to be blamed for his inability to draw nice distinction necessary between systematic oppression and a misgovernment which renders oppression systematic." ... "The question is, how long is the Slav to be required to wait for the amelioration?" The Times, August 30, 1875, 6.

${ }^{14}$ Those were not the lonely examples of narratives portraying Muslims from Bosnia and Herzegovina and elsewhere in the provinces, beyond the supervision of the European representatives in the centre, as by far worse than Turks themselves. Gladstone also expressed such attitudes, as well as some other well-read authors in Great Britain. Gladstone "made public" that the Muslim minorities and land owners were more fierce oppressors of the Christian population than Turks themselves. For Gladstone, "the central agency at the capital, always under the eye of the representatives of the European powers and in close contact with them, has acquired, and traditionally transmits, a good deal of the European speech and thought. It is when they try to convey these influences to the provinces and the subordinate agents, who share little or none of that beneficial contact and supervision". Also, William Miller, the author of one of the most read histories of the Ottoman Empire from the $19^{\text {th }} \mathrm{c}$. shared a similar opinion that included the "convert" Bosniaks, portraying them as the most fanatic Muslim oppressors of Christians. "... some of the worst oppressors of the Christians in Turkey were not Turks at all, but converts from Christianity”. Gürpinar 2012, 358.

${ }^{15}$ The Times emphasised that the dependence of Christian peasants on the Muslim land owners in Bosnia and Herzegovina had been more prominent than anywhere else, and that the oppression of Christians in their mutual relationship had the worst possible form. The Times, August 19, 
the unpreparedness and inability to radically implement the reforms and to change the succeeded administrative system that had enabled the oppression of Christians. Maladministration, the perception of oppression and unpreparedness to implement reforms and fix the subjects' systematic and true position, caused hatred among the Christians in Bosnia and Herzegovina in some parts of the province towards Muslims, and, in the final instance, to start an uprising against the local authority representative and the local Muslim elite, i.e., against the sultan and his rule.

A narrative was constructed that the Christians could no longer wait for the real improvement of their situation, hence, they only saw the way out in an uprising against the oppressive authority. Although the external influence to the organisation, initiation and maintenance of the uprising was not negated, The Times' narrative saw the main cause of the uprising in the oppression of the Christian peasants. ${ }^{16}$ Christians "who suffer by Muslim greed and oppression" increasingly acquired sympathy in all European countries that were considered major powers at the time. In those countries, even in Great Britain, who was a traditional protector of the Ottomans, all hope faded that "Turks would repent" and change the behaviour towards the Christian population. ${ }^{17}$ Prior to the uprising, Christians saw the only true protection from the local authorities' oppression in the consular representatives of major powers. ${ }^{18}$

The fixation of the narrative on a continual oppression of the Christian population as the main cause of the uprising was aided by the manner in which the rebels saw their uprising. Although their understanding of it was not always commented, the very announcement of memorandums of the uprising and other opinions that supported the uprising fixated the narrative on a systematic oppression of the sultan's Christian subjects in Europe as the main cause of the uprising. The use of judgmental terms in such texts, such as the Turkish tyranny, barbarism, persecution, violence and oppression, constructed, in the British public, a strong, negative image of the Ottoman authority and the local Muslims, as well as empathy

1875,7 . The editor concluded in the discussion on June 19, 1875 that oppression dominated the Ottoman Empire, including Bosnia. The Times, June 19, 1875, 9.

16 "... the deep oppression which weighed upon them and forced them to rise against this atrocious tyranny." The Times, September 10, 1875, 8; 26. He emphasised that the uprising in Herzegovina started because of the "intolerable oppression". The Times, November 26, 1875, 7. See more on the opinion on the situation of the deep oppression in The Times, January 5, 1876. 6. On 10 February 1876, The Times quoted a section of Gladstone's speech in the House of Commons at the British Parliament, where he stated that the uprising was caused by an intolerable oppression. The editor praised Gladstone's opinion, agreeing with it. The Times, February 10, 1876, 9.

${ }^{17}$ The Times, August 14, 1975, 9; The Times, August 30, 1875, 6.

${ }^{18}$ The Times, September 12, 1875, 5. 
towards the rebels and Christians in general. ${ }^{19}$ The English public, which had a developed sense of humanism and Christian solidarity, was also influenced by the opinions published in The Times that stated that the cause of the uprising was by no means political in nature, but primarily it was the social injustice, class and religious persecution..$^{20}$

On the occasion of publishing some "interesting" official documents related to the cause of the uprising in Herzegovina, The Times' discussion stated also the issue of land relations between the Christian peasants and Muslim land owners. The Times editor believed the rebels who stated that their intention was not to rebel against the sultan, rather, they rebelled against the oppression in the province. The uprising that the Ottoman authority tried to sever developed from the war against oppression to the war against the sovereign. The Times concluded that the rebels had no other choice but to either resist the sultan or accept the authority that failed to protect them "from intolerable oppression". The first demands the rebels presented to Derviš Pasha were not political; they asked for the protection of their basic rights: to prevent the abuse of Christian women by Turks; to protect their churches; to have the same rights at the court; to be protected from police violence; to prevent the tax collectors from taking more than it was prescribed; to set the taxes per a household to less than a ducat annually and to annul the forced labour. The editor stated that, as it had been expected, they did not agree to Derviš Pasha’s demand to lay down their arms, since they did not believe that neither he nor the Turkish government would fulfil their demands, just as they had failed to control the "pompous fanaticism of Muslims". ${ }^{21}$

${ }^{19}$ The memorandum of the rebels to the international committee, stated, among other, that the uprising against Turks happened in order to "prove to the civilised Europe of the $19^{\text {th }}$ century that it was a shame and a holy sin letting such barbarism exist." They added numerous other accusations against the local Muslim population, in an attempt to prove the continuity of violence against Christians in Bosnia and Herzegovina, as well as the situation of utter lawlessness. They especially emphasised their affiliation to Christianity and Muslim insults of Christians. They stated also "The Turks carry away by force our wives and daughters, and force them to embrace Islamism. If a Christian comes forward against a Turk, he does not live three days." The Times, October 2, 1875, 5. The Times correspondent from Vienna expressed the opinion of the Mostar archbishop "Kraljevich" that there wasn't a sane person who doubted that the people of Bosnia and Herzegovina initiated the uprising because of "the gross maladministration and oppression they were exposed to .... The Times, October 19, 1875, 10. On February 7, The Times quoted Serbian metropolitan Mihailo on the Turkish oppression of Christians in Bosnia. The Times, February 7 , $1876,10$.

${ }^{20}$ In discussion the causes of the uprising, a special correspondent to The Times from Herzegovina stated that the motifs for the uprising were class and religious persecution, as well as an absolute impossibility of Christians to receive a just treatment from the Muslim authority. "On this point there is no difference of opinion that the Turkish system is inseparably connected with injustice to the Christian, and in general, also, to the poorer Mussulman." The Times, November 11, 1875, 8.

${ }^{21}$ The Times, December 15, 1875, 9. 
Similar narratives on the dominant "Turkish sin" for the disturbance of the European peace, which was contained in their system of governance and socioeconomic pressure on the Christians (especially peasantry), can also be observed in the Daily News, with a more open and a stronger anti-Ottoman sentiment. Also, a stronger engagement of the editor is seen, in comparison to The Times. The Daily News also expressed concerns over the European peace, hence, they expressed the attitude that the Herzegovina uprising took place in the most unsuitable moment, but the conclusion was that the rebels who decided to rebel against the Turkish oppression clearly sent a message who was to blame for jeopardising the European peace. ${ }^{22}$ More concretely, it is stated that the Christian peasants were subjected to oppression and extortion by the local tyrants against whom they had no possibility to complain, and that had created an entire narrative about the collective guilt of the local Muslims (the local tyrants) and the Ottoman state and its state system (bad administration and inability to seek justice and be protected from injustice). The editor claimed that the reports by the British consuls from the entire Ottoman Empire presented evidence on the difficulties in collecting the one third in-kind taxes and on a "cruel oppression inflicted on the rural population in the process." It was repeated on several occasions that the uprising started because of the extremely bad position of the rural population, which also included the tax collecting procedures. Because of the bad taxation and land system and a constant oppression, the peasantry was in the state of a constant revolt, leading to an open uprising in Bosnia and Herzegovina. ${ }^{23}$

Similar to The Times, the Daily News opened space for the presentation of the uprising, speaking of causes of the rebellion and, in general, the Ottoman system of rule from the Serb angle. In that section of the narrative construction, a significant space was open for presenting the Daily News as the most significant representative of liberal ideology. Striving towards the introduction of the principle of morality in the international politics and the support to the "slaved" Slavs against the Ottoman

${ }^{22}$ Daily News, September 29, 175, 4.

${ }^{23}$ Daily News, October 25, 1875, 5; Daily News, January 7, 1876, 4. See also: Daily News, November 25, 1875, 4. and Daily News, May 22, 1876, 5. In the article by a permanent correspondent of the Daily News from Constantinople, entitled "Position of Turkey", the conclusion was that the uprising in Herzegovina and in Bulgaria started because of a systematic oppression. "The oppression to which he objects does not come from one man, but from the iniquitous system of which that mains the head." ... The correspondent advocates that the Christians enter the Ottoman military system, for, as he said, if a man with a bayonet cannot be oppressed, then the oppression will stop, or it will become an exception rather than a rule. He recommended to Disraeli that, if he were to conduct the politics of strengthening of the Ottoman authority, that including Christians in to Army would be the right position to take so as to express equality of all. Daily News, June $20,1876,6$. 
Muslim rule is sensed. ${ }^{24}$ Empathy towards Christian Slavic population is seen in Daily News texts that treated the Bosnian and the Balkan issue, as well as opinions on the insufficient attempts to deem the poor Muslim population among the threatened and the oppressed. For example, on 3 June 1876, the newspaper published the Bosnian Committee proclamation for the Muslim peasantry, which, among other, reads that they had rebelled against the oppression, exploitation, maltreatment, murder, lawlessness, insults, and similar injustices by the Ottoman masters and the local agas and beys. ${ }^{25} \mathrm{~A}$ translation of the Bosnian refugees' petition was published and presented to Barron Mollinary, the governor of the Croatian military border, which, among other, reads: "After so many years the oppression has become worse and worse." Commenting the petition, the editor especially focused on its allegations that the refugee Christians would not go back to Bosnia as long as Turks lived and ruled there, because the Bosnian Muslims would not and did not want to accept the sultan's reforms; rather, they angrily refused them. The petition expressed fear over possible death and violence that awaited the returnees. ${ }^{26}$ The editor concludes that it would be impossible to neglect the appeals contained in the Bosnian Petition and adds: "it seems impossible to find a way out of difficulties as long as the country of these unfortunate people is in the state of anarchy and violence.".

Unlike The Times and, especially, the Daily News, The Pall Mall Gazette and their editor frequently observed the situation in Bosnia and Herzegovina related to the uprising and its causes trough a multi-perspective angle, expressing different views on the issue. ${ }^{28}$ In a comprehensive, analytical discussion of 24 August 1875, entitled "Outbreak of Herzegovina", the editor speaks of two possible scenarios of events in Bosnia and Herzegovina. One possible scenario suits the image created in The Times

${ }^{24}$ On June 10, 1876, a private letter from Belgrade was published, speaking of the criticism of the British authorities for supporting the Turkish national system and the struggle of Slavs for freedom against the Muslim rule, as well as of a complete mistrust in the Ottoman reforms and the "horrible oppression". Daily News, June 10, 1876, 5.

${ }^{25}$ The proclamation stated that the uprising started "because of the oppression of our Osmanli lords, of our Spahis and Begs, has been too much for us. They have fleeced us, killed, ill-treated, hunted, insulted us, and taken our last morsel out of our mouths." Daily News, June, 3, 1876, 3.

26 "Return to Bosnia while the Mussluman rules there would be surrender of the men to death and the women to outrage." Daily News, April 25, 1876, 5.

${ }^{27}$ Daily News, April 25, 1876, 5. On June 14, 1876 a letter to the Daily News editor from Belgrade was published, talking, among other, about refugees (about 150,000 of them), who had found shelter in Serbia, Croatia, Dalmatia and Montenegro, and who had fled their homes because of the Turkish oppression. Daily News, June 14, 1876, 2. Similar to the Daily News, the Bristol Mercury commented the situation in Bosnia, emphasising the "oppressive and exacting Mussulman rule in the disturbed districts of Bosnia and Herzegovina." Whitehead 2014, 127.

${ }^{28}$ The Pall Mall Gazette, August 24, 1875, 1-2. The editor opens the issue of the uprising through a multi-perspective angle, commenting on whether or not the only and true cause of the uprising was oppression - The Pall Mall Gazette, January 19, 1876, 1. 
and, especially to the liberal readers presented in the Daily News, which one-sidedly places the blame to the Ottoman Empire, its system and manner of rule, threatening thus the European peace and initiating the Herzegovina uprising which later spread to Bosnia. Oppression, misgovernment, possible massacre of Christians by the local Muslims, economic, religious and a widespread normative and practical inequality, initiated the "second-rate citizens" to rebel, for they could no longer suffer injustice and oppression. On the other hand, The Pall Mall Gazette tackled the consular reports, interpreted the causes of the uprising, similar to consul Holmes, creating thus a second image of the uprising and the systematic and non-systematic causes of the uprising, close to the image created by consul Holmes in his reports from Bosnia and observations on the relationships in Bosnia and Herzegovina before and during the uprising. Similar to consul Holmes' discourse, The Pall Mall Gazette did not react against the severe condition of the Christian population and other issues in the Ottoman Empire regarding reforms. However, those were not the only, not even the dominant causes for the disturbance of the British public. The editor of The Pall Mall Gazette directly links the causes of the uprising to a possible need of a humanitarian intervention. ${ }^{29}$ In his discourse of the dual cause of the uprising (socioeconomic and national-political), it appears that the second image dominates, that there would not have been the uprising in Herzegovina had Herzegovinians acted alone; rather the uprising "(is) the work of foreign missionary". Foreign agitators and foreign countries are the ones who used "the belligerence of highlanders" and initiated their rebellion. In this phase (late August 1875), the editor was of the opinion that the enduring oppression was more of an excuse for the uprising rather than its real cause. ${ }^{30} \mathrm{He}$ also mentioned a theory (without a proof, as he stated) that the cause of the rebellion could have been a Russian attempt to solve the Eastern Question, or even a desire of Germany to distance Russia from the western affairs. In that case, the Turkish affairs would have mostly been beyond the Turkish power. ${ }^{31}$ Here too, the editor preserved the multi-perspective approach, opening a possibility of rational negotiations regarding this theory. If the uprising had been caused by a latent displeasure of the Christian population, then it would have been a far better situation for Turkey, since it would have been able to use military to end it. However, the problem in such a solution to the crisis he saw in the fact that both Herzegovina

${ }^{29}$ He wrote: "if we were to believe that the weak Ottoman ruler and his authority representatives were the only ones to blame, then we would agree with the opinion... that the British intervention would benefit the situation." The Pall Mall Gazette, August 24, 1875, 2.

30 “... if Christians under Mahommedan rule could ever think that an excuse were needed." The Pall Mall Gazette, August 24, 1875, 2.

31 "If the insurrection in the Herzegovina is the work of a foreign propaganda, the key to Turkish politics must no longer be looked for at Constantinople. It has been transferred to St. Petersburg or to Berlin." The Pall Mall Gazette, August 24, 1875, 2. 
and Bosnia were connected to Montenegro and Serbia, the countries inhabited by the same population, all belonging to the Orthodox Church, like Russians. ("Christian population of all these provinces are allied by race to the populations of the border provinces of Austria, and by religion to the population of the whole Russian empire."). Because of all that, it would be impossible for Austria and Russia to stand still, looking at the Ottoman Empire terminating the uprising in a cruel manner, "which is what it normally does when it ends an uprising". The Pall Mall Gazette editor considered impossible for Russia to peacefully observe the Muslim terror over Orthodox Christians, for that would discredit the Russian authority among them. If the Ottomans had used force to end the uprising, it would have been judged and perceived as cruelty and annihilation of the sultan's Christian subjects; Russia and Austria would have interfered, and that would have sent a clear message to the Christian subjects of the Porta that in any further clash with their ruler, they would be protected by the three emperors (Russia, Austro-Hungary, Germany) from all undesirable consequences arising after the expression of disloyalty. ${ }^{32}$ The Pall Mall Gazette expressed suspicions in the cooperation between Great Britain and Russia based on the morality principles, for the purpose of protecting from oppression the Christian population of Bosnia and Herzegovina and elsewhere in the Balkans from the Ottoman rule and Muslims. The editor did not believe in predominantly humanitarian motifs of Russia that supported the Balkan Christians against their sovereigns, emphasising that he found it hard to believe such a thing since Russia also oppressed its own subjects, for example, in Poland. ${ }^{33}$

The Pall Mall Gazette editor was aware of difficulties of the pacification of Bosnia and Herzegovina. On 7 October 1875, he analysed the manifest of the rebels from the Austrian border. Although he expressed reserves that all that was written was true, he stated that because of the fact that those people had sacrificed themselves, their families and land and rebelled, their objections to the Turkish government needed to be seriously considered, as well as that it was necessary to believe that the criticism of the Ottoman authority by the local Muslims was not vastly exaggerated. In short, the rebels stated that the causes of the uprising were bad and unjust authority, severe economic situation, intolerable Islamic religion, violence of tax collectors, inability to complain, corruption and corrupt courts. Although careful to accept the one-sided causes, the editor was of the opinion that in dealing with the uprising one needed to consider such a perception of relations in Bosnia and Herzegovina. ${ }^{34}$ He was of the opinion that it wold be difficult to

\footnotetext{
32 The Pall Mall Gazette, August 24, 1875, 2.

${ }_{33}$ The Pall Mall Gazette, February 21, 1876, 10.

34 "... we have a population who show their profound belief in the oppression they allege by risking everything to free themselves of it." The Pall Mall Gazette, October 7, 1875, 1.
} 
improve the relationship between "Turks" and their Christian subjects, ${ }^{35}$ by which he did not essentially distinguish the Ottomans and the local Muslims.

In the spirit of multi-perspectivism and for the purpose of providing full information to the readers, The Pall Mall Gazette followed the activities of associations that had an anti-Turkish sentiment, who saw the main cause of the uprising and problems in the oppressive Ottoman rule. For example, on 10 October 1875, the Pall Mall Gazette published the information on the conference "the friends of the suffering rayahs of Bosnia and Herzegovina" that was held on 9 September in the Cannon Street Hotel in London. It was chaired by Mr. J. J. Merriman, while the keynote speakers were Mr. J. L. Farley and Rev. W. Denton, an Ottoman Christians' rights activist. A resolution was then adopted stating that the oppression and injustice that the Christians in Bosnia and Herzegovina were subjected to caused sympathy and help with the Christian people of England. They "provide support so as to liberate them from the evil that torments them" (Turks). ${ }^{36}$ The Pall Mall Gazette also presented information from The Times and other newspapers regarding the class and religious oppression of Christians in Bosnia and Herzegovina and inability of Christians to receive justice from the Muslim administration. ${ }^{37}$ Although they did not insist on the social, but rather on predominantly religious oppression of Christians by Muslims, they did not comment that they were quoting The Times, and that the poorer Muslim population also suffered injustice by the Ottoman and the local rulers. They also did not comment the opinion of The Times correspondent from Herzegovina that Christians, if granted autonomy, would oppress Muslims. That opinion opened way to a humanitarian intervention in the sense of an international military intervention or a foreign occupation. ${ }^{38}$ They would also frequently quote, without a commentary, the writings of foreign newspapers that the rebels started to rebel because of the heavy taxes and oppression. ${ }^{39}$ Letters to the editor were also published, stating opinions on oppression as the main cause of the uprising. ${ }^{40}$

35 The Pall Mall Gazette, October 7, 1875, 1.

${ }^{36}$ The Pall Mall Gazette, September 10, 1875, 4. The Pall Mall presented the information from the conference organised by the League in Aid of the Christians in Turkey, mentioning that Christians had been subject to "grievous oppression." The Pall Mall Gazette, April 1, 1876, 6.

${ }^{37}$ The Pall Mall Gazette quoted the writing of The Times, where their special correspondent from Herzegovina presented the opinion that the cause of the uprising was not the current oppression, but an oppression that had lasted for some time. The Pall Mall Gazette, March 6, 1876, 9. They also quoted The Times writing about an "intolerable oppression" of Christians in Bosnia. The Pall Mall Gazette, January 15, 1876, 2.

${ }^{38}$ The Pall Mall Gazette, November 11, 1875, 8.

${ }^{39}$ For example, Official Gazette from Petrograd. The Pall Mall Gazette, October 30, $1875,7$.

${ }^{40}$ An influential motivator of the anti-Russian agitation, E. A. Freeman, wrote to the Pall Mall Gazette editor on several occasions, consistently expressing the opinion that the cause of the uprising was a constant oppression of Christians by the incapable Ottoman rule. See: The Pall 
The discourse in The Pall Mall Gazette does not contain any instances of morality in international politics, or any other concept that primarily does not consider the priority British national (imperial) interests. Although the emphasised multiperspectivist approach differentiated them from The Times and the Daily News, they by no means reacted against the oppression of the Christian subjects or the misgovernment of the Ottoman Empire; rather, they used the approach to support the British conservative government in an attempt to preserve its position in the world. In this discourse, the Turks were the culprits for jeopardising peace, but a greater guilt fell to a foreign element, primarily Russia, an old British opponent in the East. The truth is that one cannot fully deny the expression of solidarity towards the people suffering in the Balkans, but even in such instances, what dominated were the careful, "rational" proposals that would not turn the suffering of the minority into the suffering of the majority. The care for Christians of Bosnia and Herzegovina, as well as for the BiH Muslims, was not primary for them.

\section{Oppression as an Argument for (Humanitarian) Intervention and Western (Austrian) Occupational Right}

Since the dilemma on whether or not Christians were suffering oppression was fading, The Times quite early started discussing the possibility of a humanitarian intervention in the "European Turkey". In view of a more serious action against the Ottoman rule, The Times editor considered in the first year of the uprising that the Ottomans were saved by the real fear that a more serious intervention of powerful countries, because of their discordance regarding the Eastern Question, couldjeopardise the European peace and the balance of power. For The Times, peace in the east of Europe (and in Europe) would be unmeasurably more important than the wellbeing of Christians in Herzegovina. According to the editor, the wellbeing of Christians in Herzegovina had to be put on hold..$^{41}$ The foreign (humanitarian) intervention was more visibly advocated by The Times correspondents from Herzegovina and Pera, ${ }^{42}$ for, as they stated, inability to reform the Ottoman state system on the principles of equality and equity, as well as due to the expectation that, in case of establishing the local (Christian) autonomous rule, the local Christians would oppress the local

Mall Gazette, December 15, 1875, 2-3; The Pall Mall Gazette, February 14, 1876, 3. In a letter published on 24 April 1876, he speaks of a continuous oppression, adding that the Muslim soldiers themselves were also oppressed by the common tyrant. The Pall Mall Gazette, April 24, 1876. See also: A similar E. A. Freeman's letter. The Pall Mall Gazette, February 28, 1876, 3.

41 "The miserable situation of the oppressed Christians is a lesser evil than a destructive war that could bring into question the existence of the Ottoman Empire and a discordance between Europe's major countries." The Times, August 14, 1875, 9.

${ }^{42}$ Pera is a part of Istanbul, Beyoğlu. 
Muslims. ${ }^{43}$ Indigenous Balkan Muslims ("there are millions of them") would not accept a Christian governor, and the negative experience of Slavic Muslims in Serbia and Montenegro was a warning against the creation of the new Christian principalities in the Balkans. ${ }^{44}$ The Times correspondent from Berlin discussed in September 1875 the "rational motifs" of Austria to annex Bosnia and Herzegovina to its Slavic areas, provided the preservation of the sultan's sovereignty, emphasising that one of the motifs was also liberation of Bosnia and Herzegovina from the Turkish oppression. ${ }^{45}$

The Times also wrote that a systematic oppression of Christians by the Ottoman rule and the local Muslim population had its roots in a deep religious hatred among the "brotherly" population of Bosnia and Herzegovina, which had resulted in the outbreak of violence that could not have been stopped without a foreign humanitarian intervention. In a discussion from 19 November 1875, the editor considered the relationship between these facts; he started with the statement that the only salvation from a complete disaster in Herzegovina was a foreign occupation, since, according to him, the interreligious hatred was so intense that the only goal of the warring sides was "to have each other's throats slit". In order to reinforce this attitude, he stated some unreliable information on the preparations of Muslims to massacre Christians in some places where the uprising did not spread. He added that the massacre had not taken place only because of the Turkish commanders' supervision, "who know that the repetition of the 'Syrian crimes'" would mean the end of the Ottoman rule. In the same tone, he expresses the opinion that Christians were most probably just as ready to massacre Muslims, if they seized an opportunity. He sees the cause for that in years of oppression and insults that had filled the raya with hatred towards the "dominant race". ${ }^{46}$ Comparing the relationship of the $\mathrm{BiH}$ Christian peasant and the $\mathrm{BiH}$ Muslim landowner with other cases (the French peasantry and nobility, Russian and Polish peasantry and nobility), he concludes that the opposites had nowhere reached such a level of animosity as was the case with the Turkish (Bosnian) case. In this and similar attitudes of The Times editor, as well as in other mentioned and unmentioned texts in this newspaper, a clear orientalist discourse on civilizational dominance of the West over the barbaric East is observable, where the Eastern

${ }^{43}$ The Times special correspondent from Herzegovina concluded: "Turkish system is inseparably connected with injustice to the Christian, and in general, also, to the poorer Mussulman. It is useless to reform a system which is rotten to the very base. It must be wholly replaced ..., but not from within, for it is impossible". The Times, November 11, 1875, 8 .

${ }^{44}$ From The Times correspondent from Pera dated November 20. The Times, November 30 1875, 6.

45 "Bosnia and Herzegovina be freed from Turkish oppression, yet left sufficiently under control of Turkey to prevent their dabbling in foreign policies." The Times, September 4, 1875, 3.

46 "When people are treated like brutes for generations, it is certain that in time they will act like brutes. Now, the peasantry of Herzegovina and Bosnia have endured more grinding insults and oppression even than the Greeks themselves." The Times, November 19, 1875, 9. 
manner of rule at micro and macro levels had resulted in irreconcilable oppositions with bloody consequences that were impossible to eliminate without a military humanitarian intervention (occupation) as a precondition for "more sophisticated methods" of raising the cultural and civilizational level of the local population. ${ }^{47}$ Such an orientalist discourse contains key elements of the western ottomanism and balkanism ${ }^{48}$ : The Ottoman Empire cannot be transformed in the spirit of the western model of freedom and liberty, while the former sultan's subjects in the Balkans, due to a cultural stagnation that they had endured under "Turks", ripped away from the wing of the Christian Europe, cannot independently construct a political identity that would be open towards the Other and the different. ${ }^{49}$

Similarly, only in a more open manner, the Daily News painted a picture of the Muslim and Christian population in Bosnia and Herzegovina, trapped in the Ottoman system which had categorised them into different political, socio-economic and identity categories. The local $\mathrm{BiH}$ Muslims had accepted the Ottoman Empire as their own and were ready to maintain it, together with their own positions, and go to the ultimate limits of violence; on the other hand, Christians too were ready to commit cruel violence against the local Muslims, as a method of revanchist tendencies and a desire to change the existing situation. the Daily News did not believe in the reformation of the Ottoman Empire, and it did not want a complete control of the Ottoman Empire over the European Christians. That newspaper was open for all other options, from providing self-governance to the local Christian population ${ }^{50}$ - which was the attitude The Times did not

${ }^{47}$ For an example of the sophisticated methods in the Austrian imperial politics, see: Kasumović/ Radušić, 2017.

${ }^{48}$ Edhem Eldem, in the article The Ottoman Empire and Orientalism emphasises that although some orientalist tropes for describing the Ottomans in the period when they, or, at least, a considerable section of their political elite, were striving for the administrative and social transformation in accordance with the western model, in the $19^{\text {th }}$ century, an archetypal model of orientalism was created according to which the Ottoman Empire of the $19^{\text {th }}$ century could have created a bit more than the hybrid and degenerative form of semi-civilisation. Eldem, 2011, 91. Although she denounces the opinion that Balkanism is a subclass of orientalism, rather, she deemed it another kind of western perception of the other (the Balkans is the European other, unlike the Orient which is the other, Todorova 1999, 22-44), Maria Todorova, in deconstructing the western image of the Balkans, essentially arrives to the same conclusions on the created discourse about the civilizational supremacy of the West and the consequential right to politically decides on (rules over) the Balkans, for the sake of the European (global) future. Todorova 1999.

${ }^{49}$ The British liberal representatives were also, in a way, a part of the Balkanist discourse. And that includes even Miss Irby. Perkins 2014, 44-45.

${ }^{50} \mathrm{On}$ the occasion of a discussion in the House of Commons of the British Parliament, concerning the withdrawal of the Berlin Memorandum, the Daily News editor advocates the right of the Christian population to self-governance. A refusal to support such a proposal would, according to him, mean "to send (Christians) to an inevitable oppression." Daily News, June 10, 1876, 4. 
favour - to the foreign occupation as a type of humanitarian intervention. In an article, the Daily News editor emphasised that the sultan's victory in the Balkans would not restore peace and order under good government. That would only renew the anarchy and oppression that motivated the non-Muslim population of Bosnia and Herzegovina to rebel. The Ottoman Empire was described as a state that failed to implement the obligations and was breeching the promises. He was against the possibility of Turks receiving the reward for bad behaviour in the uprising in the provinces that rebelled, hence, they would not receive support from Great Britain. The author of the text further looked for a solution that would benefit the peoples of Eastern Europe, not the Ottoman Empire. ${ }^{51}$

In the spirit of openness in the process of finding a solution to the crisis, with the exception of the restoration of a direct Ottoman rule, this newspaper was, to a certain extent, ready to recognise the Russian role in the protection of Christians from oppression, and to admit that this country was the leader of the group of countries seeking an exit from the crisis and who protected the European peace (together with Germany and Austro-Hungary)..$^{52}$ The Daily News also considered the option of solving the crisis by Austrian occupation of the rebelled provinces. ${ }^{53}$ Apart from all the deficiencies that the Daily News editor noticed, he assumed a positive attitude towards the Andrássy's note. ${ }^{54}$ However, he was of the opinion that a problem could arise in the implementation of the note because of the disturbed relationship between Christians and Muslims, who should, once the situation in Herzegovina settled, work together in the plan implementation committees. The

51 "... and we may cherish the hope that, whenever the opportunity offers, we shall be able to do something for interests of good government and welfare of populations in Eastern Europe." Daily News, May 22, 1876, 5.

${ }^{52}$ As an argument to this, we will mention that the Official Gazette published an article from St. Petersburg in that spirit, which the editor did not deny. Daily News, June 7, 1876, 4-5. Still, the editor did express opinion elsewhere that the Russian imperial interests had exposed the Christian population to severe oppression. Daily News, June 7, 1876, 4-5.

${ }^{53}$ Daily News, November 25, 1875, 4.

${ }^{4}$ The Andrássy's Note saw the problem in Bosnia and Herzegovina because of the nonimplementation of the proclaimed reforms and inequality with Muslims. The proponent stated that the ultimate goal of the note was to preserve the European peace, and that could be achieved through: full freedom of religion for all; annulment of the tax lease system (urgently in Bosnia and Herzegovina); a law that would guarantee that the funds collected from the direct taxation in Bosnia and Herzegovina would be used to suit the needs of the province; establishing a special committee consisting of an equal number of Muslim and non-Muslim members, whose task would be to supervise the implementation of reforms proposed by major powers, as well as the ones proclaimed by the irada (the sultan's proclamation) issued on 2 October and the firman (a decree) issued on 12 December 1875; improving the position of the rural population. Radušic 2013, 287-288; Andrássy-Beust, Budapest, December 30, 1875, No. 55, Turkey, No 2 (1876), 74, 79; Jakšić 1955, 10. 
source of the problem in the relationships within Bosnia and Herzegovina was seen in a bad treatment of the local Christians by the local Muslims ("there are being treated like sheep or dogs"), which resulted in hatred in the opposite direction. ${ }^{55}$ Due to an attitude and opinion according to which one could not expect Muslims and Christians to respect one another, a space was open for solving the crisis and for preserving the European peace, in accordance with a proposal from Europe.

The Pall Mall Gazette, in discussions about possible solutions to the Eastern Question, started from the attitude that it was difficult to make the Ottoman government to secure autonomy for the rebelling provinces. Although the Ottoman Empire had allowed to recognise autonomy to the Danube provinces and to Serbia, The Pall Mall Gazette editor was of the opinion that the situation in Bosnia was entirely different. The central place in deeming the situation in Bosnia and Herzegovina different was the number of the Muslim population. The number was significant especially in cities, but in villages as well. Also, Muslims were landowners. Furthermore, the problem would be in the fact that the rebelled provinces could not be separated from the direct control of the Ottoman authority without the previous withdrawal of the Ottoman garrisons. In such a scenario, Muslims and their property in Bosnia and Herzegovina, under a possible Christian rule, would, according to the editor, be less safe than the very Christians under the direct Ottoman rule. Another possibility that was discussed was the occupation of Bosnia and Herzegovina by a neighbouring force (Austro-Hungary or Russia) for the sake of the European peace. This scenario too was not attractive to The Pall Mall Gazette editor. He was not sure about the manner in which a foreign occupational force, if it assumed the role of a policeman, would solve internal differences between the Muslim landowners and Christian peasants. The third possibility that was discussed in The Pall Mall Gazette were possible important changes to the land system that the Ottoman Empire would make for the purpose of satisfying the Christian population. In this case as well, The Pall Mall Gazette editor was not optimistic, since the Ottoman Empire did not show readiness to make a revolutionary move into the ownership issued and thus deprive the structure loyal to the Ottoman state. The fourth solution to the Bosnian issue would include a possible pacification of the uprising by force. That too was not a realistic scenario. Although the Ottoman Empire would take a wide offensive with the use of a significant military force, due to the inaccessible terrain and the support from Serbia and Montenegro, the uprising would not end, even if those two principalities remained formally neutral. This way of solving the crisis was aggravated by the real fear of the Ottoman Empire of a possible reaction by the major powers, which would, after some incident, turn the uprising into a "regular war". ${ }^{56}$

\footnotetext{
${ }^{55}$ Daily News, January 7, 1876, 4.

56 The Pall Mall Gazette, October 7, 1875, 1.
} 
While analysing the treatment of the uprising in Bosnia and Herzegovina in The Pall Mall Gazette, I found, in a number of texts that treated different issues related to the uprising and the Eastern Crisis, another comprehensive editorial discussion about possible solutions to the crisis. ${ }^{57}$ This reflection was initiated by an article of the already-mentioned representative of the liberal opinion about the uprising in Herzegovina, Edward Augustus Freeman, published in the Fortnightly Review. The editor here to a large extent agreed with Freeman's remarks that the misuse of the Turkish rule was the cause of the uprising, and that Turks, even after five centuries long presence in Europe, were still conquerors in nature who had failed to turn the conquering authority into national. ${ }^{58}$ Such an attitude strengthens the conclusion that even the pro-government newspapers did not, to a significant extent, deviate from the ultimately negative remarks about the Turkish government and the character of Turks, and that the main difference in comparison with the leftist (Daily News) and centrist (The Times) newspapers was in the defence of the eastern politics of the conservative government, not the Turks.

The Pall Mall Gazette editor accepted that E. A. Freeman was, to a significant extent, a spokesman for the English, emphasising that he would receive a $99 \%$ support of the fellow countrymen for his attitude that the Turkish authority in Europe was an "odious tyranny", and that it had caused a just rebellion of the sultan's Christian subjects. ${ }^{59}$ Because of such an attitude and opinion according to which one cannot expect for Muslims and Christians to respect one another, a space opened for solving the crisis and preserving the European peace that would be proposed by Europe. However, The Pall Mall Gazette, in the spirit of support, did not follow Freeman's conclusion that, because it was rotten, oppressive and unable to truly reform itself and offer real equality to subjects of other faiths, the Ottoman Empire needed to immediately end in Europe. Freeman advocated humanitarian intervention of the civilised Europe, so he saw the termination of the Ottoman authority in its European provinces by the use of the strength of the European powers. ${ }^{60}$ In order to

57 “Two views on the Turkish Question”, The Pall Mall Gazette, December 10, 1875, 1.

58 "His main position, that the Turk, even after five centuries of European sway, is essentially a more invader of the territory which he holds in Europe, may be admitted without much dispute, and his description of the character of the invader's government is doubtless accurate." The Pall Mall Gazette, October 7, 1875, 1.

${ }^{59}$ Certain circles considered E. A. Freeman an advocate of the enslaved Balkan Christians; observations about the events in the East were sent to him, and he would forward them to newspapers. See an example in the Daily News, August 24, 1876, 2.

${ }^{60}$ Without an editorial comment, a long letter by Edward A. Freeman was published on 15 December 1875, in which he offered a solution of the liberation of Bosnia and Herzegovina. According to him, Austria could manage on its own, but it would be better if Austria and Russia worked together, and by far the best if all powers acted together. He was convinced that a good diplomatic action could bring results, and especially a seven-week-long military intervention, or a week-long 
convince "Europe" into the necessity of a humanitarian intervention, he presented two possible scenarios: either "Turk must go or he must cease to be a Turk", or Bosnia and Herzegovina would die. That, to him, was the true Eastern Question. ${ }^{61}$

Notwithstanding the considerable support to Freeman's attitude regarding the character of the Ottoman rule and Turks, the editor understands the Eastern Question in a much wider and complex manner than Freeman's definition. He doubted that the joint voice of Europe would make Turks give up their provinces peacefully, and that the considerable pressure on "the sick" could cause him to disobey, and that was the reason why the European powers were not making a direct pressure. Unlike Freeman's dilemma placed before those who made decisions - to simply make a choice between good and evil - the editor expressed a different opinion regarding the task of the great powers - to choose between two evils: to accept the existence of the tyrant authority that can never successfully undergo reforms, or to attempt to terminate it, with a probability of initiating the worst and the bloodiest war. According to the editor, Freeman was a dedicated hater of oppression, for whom the very act of revealing the oppression also entailed its fast termination. For Freeman and the likeminded, the path was clear: a Turk was a tyrant and an oppressive ruler who needed to undergo reforms or to step down, peacefully, if possible, and by force, if not. The Pall Mall Gazette editor expressed the main objection to such a scenario in the fact that he himself did not weigh between the misery of a tyrant authority and the misery of a vast religious war that would probably result in "an extensive massacre" of the Christian population, whose interests Freeman advocated. The editor was of the opinion that the human killing would cause an intervention in Turkey also because of the mutual struggle between the European powers. That is why he clearly opted for a careful politics and the "damage estimate" in any possible scenario. ${ }^{62}$ In strengthening the thesis about a possible bad outcome of the foreign (humanitarian) intervention, The Pall Mall Gazette was aided by The Daily Telegraph observation that concluded that the solution to the Bosnian crisis through a military occupation would be an "unwelcome" precedent, especially because Bosnia and Herzegovina did not see instances of savage massacres by Turks that had occurred in Syria, and that had caused a joint action by the European powers. ${ }^{63}$

war. He was not afraid of any vast massacre of Christians, for he emphasised that Christians then were not in a situation to be massacred. The Pall Mall Gazette, December 15, 1875, 2-3.

${ }^{61}$ Freeman emphasised: "Turk must go or he must cease to be a Turk. ... from Servia he has gone already. Bosnia and Herzegovina have given him notice to quit, and from them he must go at once. ... Which of these two alternatives is to take place is true Eastern Question.” The Pall Mall Gazette, October 7, 1875, 1.

62 "For the present we must be content with palliatives; but even this treatment is better than that which aims at the excision of the part at the expense of the whole." The Pall Mall Gazette, December 10, 1875, 1.

${ }^{63}$ The Pall Mall Gazette, November 20, 1875, 2. 
The Pall Mall Gazette did not support the thesis about the special responsibility of Austria in the crisis, unlike The Times. The Pall Mall Gazette opposed the tendency of a dialogue with the rebels, since it would practically grant them subjectivity in the process of finding a solution for the crisis. The editor advocated the return to talks between the European powers and finding solutions through the old imperial methods. He monitored the politics of the British Government and opposed the thesis that the British opting out of the Andrássy's Note could encourage Turks in their course of oppression of Christians; he was also of the opinion that the content of the document and its very appearance encouraged the rebels not to lay down their arms without the promise of an international intervention. ${ }^{64}$

Upon analysing The Pall Mall Gazette editor's discussions about possible solutions to the crisis and a possible military intervention and occupation of Bosnia and Herzegovina, as well as other texts that The Pall Mall Gazette published regarding this issue, one observes that this newspaper too was part of the orientalist, anti-Ottoman and balkanist discourse. The Ottomans were eastern barbarians who conquered a part of Europe, and who failed to make a "national" government even after ruling for several centuries, unable to implement reforms in the spirit of equality and freedom ("a semi-civilisation" à la Eldem). On the other hand, the Christian population in Bosnia and Herzegovina were unable to form their political identity that would ensure tolerance of the local Muslim population, and equality was out of the question (balkanism). The key difference between The Pall Mall Gazette's discourse compared to other (newspaper) discourses in the period prior to the events in Bulgaria in June 1876, was in that The Pall Mall Gazette was suspicious of the success of a military humanitarian intervention. Because of the complexity of relations between the European powers regarding the Eastern Question, that discourse was unsupportive of the concept of the western rule over the East in Europe, or it monitored the politics of the British Government that needed a more serious internal or external threat to the status quo in order to change its politics towards the East. Hence, at this stage of the Eastern Crisis, The Pall Mall Gazette remained at the level of an incomplete orientalism.

\section{Narrative on Crimes, Slaughter and Violence: Opening Path towards the Foreign Humanitarian Intervention in Bosnia and Herzegovina}

From the very beginning of the uprising, parallel to the events in and around the uprising area, the influential English, as well as other, press took a special interest in violence between the warring sides. Information and editors' focus on the violence over the powerless, the old, women and children left a strong impression. Unlike

${ }^{64}$ The Pall Mall Gazette, November 20, 1875, 2. 
the narrative on oppression, where the distinction between the perpetrator and the victim was clearly determined, the narrative on (horrendous) crimes, slaughter and violence saw the guilty party in both sides, but not in the same extent. The source remained the same: the eastern Ottoman barbaric rule and an especially bad behaviour of the ruling Muslims towards the Christian population in Bosnia and Herzegovina, the use of Christians by the Muslims, caused revanchist outbursts of Christians on every possible occasion. Such a web of relations in the triangle the Ottoman authority - Bosnian Muslims - Christians of Bosnia and Herzegovina that was filled with unsettling information about the real and the supposed violence of the worst kind enabled the orientalist-anti-Ottoman-balkanist approach to the Bosnian issue. Hence, a long-term solution to the issue also needed to be within the same (mixed) discourse. The aforementioned triangle produced violence that was unstoppable without the western humanitarian intervention.

The Times presented information about violence in Bosnia and Herzegovina perpetrated by the rebels, the Ottoman governmental troops and the local Muslims. For example, on 26 August, an information was published about a report that the British Embassy in Constantinople received regarding "great atrocities" perpetrated by the rebels. ${ }^{65}$ On 30 August, they wrote about a history of mutual accusations at the Herzegovina-Montenegro border on vicious atrocities. ${ }^{66}$ On 3 September they wrote about "great atrocities" on both sides in the Novi Pazar Sanjak. ${ }^{67}$ On 17 September it was emphasised that the main cause of the uprising, even more important than the oppression of Christians, was "a natural expression of mutual hatred between religious groups and the enemy churches, and that extermination and robbery were the true motifs of the uprising. ${ }^{68}$ On 19 November, considering possible withdrawal of the Ottoman army from Bosnia, The Times editor emphasised that it would be dangerous to leave the local Muslims and Christians, who had been prevented by mere state power from slaughtering each other due to the religious hatred, unsupervised. ${ }^{69}$ On 3 December 1875, readers of The Times had an opportunity to read that crimes of the sultan's troops in the rebelled area

${ }^{65}$ The Times, August 26, 1875, 3.

${ }^{66}$ The Times, August 30, 1875, 6.

${ }^{67}$ The Times, September 3, 1876, 7. A special correspondent for The Times from Pera also presented similar opinion, in a text entitled "Herzegovina". The Times, February 25, 1876, 5. The Times wrote about the acts of mutual violence also on 18 April 1876. The Times, April 18, 1876, 6.

68 " ...the details of the atrocities committed, especially by Christian part of inhabitants, indicate that it is not against the Government so much as against neighbours whom they detest which has induced them to take up arms." From an occasional correspondent from Constantinople, 17 September. The Times, September 24, 1876, 10.

69 "It seems that Muslims, in some districts, had a plan to execute a massacre over Christians, and it also seems that they were prevented by Turkish commanders." The Times, November 19, 1875, 9. 
were causing crimes of the rebels themselves over the unarmed population. ${ }^{70}$ On 15 December that same year, The Times wrote about "detestable atrocities" on both sides, since the war between the master and his serf was not without savagery. ${ }^{71}$ On 10 April 1876, The Times stated that crimes committed by Muslim soldiers and civilians would prevent any hope of pacification, ${ }^{72}$ and, eight days later, The Times correspondent from Pera wrote that he had before him consular reports of "horrible deeds" in the rebelled area, as well as of crimes that were painted such ghastly colours that the civilised readership would think they were exaggerations. ${ }^{73}$ On 5 May 1876, The Times reported of attempts by the Ottoman authorities to implement the ceasefire in the Popovo polje district in order for the people to return to their homes, while the opposers of such a scenario discouraged and frightened possible returnees by spreading the story of all kinds of crimes that the Turks had perpetrated over the returnees and Christians who did not leave their homes. ${ }^{74}$

The image of violence in Bosnia and Herzegovina in the first year of the uprising, created in Daily News, essentially did not differ from the one created by The Times. In the published information and in the Daily News editor comments, we see violence on both sides and an indirect opening of the path to a military intervention. However, the subtext shows that the main issue was contained in the Ottoman system that was unable to rise to a higher civilizational level. Not even here can we see an end to violence and a possibility of satisfying both sides. Turks lacked the capacity and did not want to meet the demands of the rebels, who refused to lay their arms without an efficient foreign guarantee. ${ }^{75}$

70 "...if the Sultans troops behave like a beast, the Christians in their turn show little mercy to their Mussulman fellow subjects." From the special correspondent from Pera, dated 23 November; The Times, December 3, 1875, 8.

71 "We should be surprised to hear that Christians have been more merciful or humane than the Turks. Mussulman oppression is not a specially good training for the nicer duties of the moral law." The Times, December 15, 1875, 9.

${ }^{72}$ From the special correspondent from Odessa dated 5 April, entitled "Bosnia", The Times, April $10,1876,5$.

${ }^{73}$ From the special correspondent from Pera dated 10 April, entitled "Invasion of Bosnia", The Times, April 18, 1876, 6.

${ }^{74}$ The Times correspondent in Vienna dated 2 May 1876, The Times, May 5, 1876, 10. The newspaper also published a similar article on 18 April 1876. They then emphasised that the Ottoman troops and the local Muslims, by the acts of violence (violence against women, murders), and following the amnesty, contributed the prevention of pacification of the province. The Times, April 18, 1876, 6.

${ }^{75}$ It is interesting that different newspapers occasionally reported about the crimes committed in the uprising, and all from the same source. Just like The Times, the Daily News and The Pall Mall Gazette wrote that a report had arrived to the British Embassy in Constantinople about "great atrocities" committed by the retreating rebels in Herzegovina. Daily News, August 26, 1875, 5; The Pall Mall Gazette, August 25, 1875, 5. 
An image was created on mutual cruel, endless violence. For example, on 27 August 1875, a telegram from Vienna was published stating that the uprising in Bosnia (and Herzegovina) caused an increase of crimes on both sides. ${ }^{76}$ On 13 September, the Daily News correspondent from Vienna passed information that a Viennese newspaper published a report by an anonymous Englishman (the implication was that the person was consul Holmes) who was told by Derviš Pasha, in tears, about incredible crimes committed by the rebels. ${ }^{77}$ We see in the Daily News too that the war in Herzegovina and Bosnia, with its "sanguinary atrocities" could last for generations without a satisfactory solution, if the events in the uprising the agreement achieved between the three northern courts. ${ }^{78}$ In that way, the possible change of the situation in the uprising and termination of crimes was directly linked to the foreign military intervention.

The Daily News also published reports and letters from the surroundings, which treated the events in the uprising. One such "private" letter was sent to the Daily News from Belgrade on 21 May 1876; the letter was published under the editorial title "Moslem atrocities in Turkey"; it spoke of the non-implementation of the Ottoman laws that benefitted Christian population, as well as of the fear of Austria and England from the Slavic liberation movement. Encouraged by the "growing admiration of the English nation for bravery and endurance, as well as the wellknown sympathies towards the poor population under any form of despotic rule" the sender of the letter made a list of Turkish crimes committed over Christians in the previous six weeks. The sender of the message claimed that Turks, the further away from the eyes of the European civilisation, the more intensively they do their "devil's deed" ${ }^{79}$ The Daily News editor did not express any suspicion in the reliability of the letter, and did not comment it. However, the information presented there essentially suited the needs of the newspaper in the creation of the anti-Turkish narrative.

The image created in The Pall Mall Gazette was almost identical to the images the readers of The Times and the Daily News could see. Crimes were committed on both sides, and the divided and warring sides could not individually leave the vicious

\footnotetext{
${ }^{76}$ Daily News, August 27, 1875, 5. There are more such examples. "Mohammedan outrages in Bosnia are causing increased agitation.” Daily News, November 1, 1875, 6. In relation to the murders of the consul in Thessalonica, the Daily News concluded that what had happened there could happen in any place where Muslims and Christian live mixed. Daily News, May 13, 1876, 5.

${ }^{77}$ Daily News, September 13, 1875, 6.

${ }^{78}$ Daily News, April 15, 1876, 4.

${ }^{79}$ The letter mentions individual names of Christians who were savagely murdered. For example, a merchant John (Jovan) Siraktich from Tešanj near Doboj was killed and dismembered. Daily News, June 10, 1876, 5.
} 
circle of violence. ${ }^{80}$ The Pall Mall Gazette wrote within their narrative about the atrocities committed in the $\mathrm{BiH}$ uprising also about the crimes that Christian rebels perpetrated against Christians who did not want to join them. ${ }^{81}$ The difference between The Times and the Daily News is only seen in a more critical relationship towards the information and opinions presented in other newspapers, except for The Daily Telegraph which assumed the same position as The Pall Mall Gazette. In that spirit, The Pall Mall Gazette published an article from The Daily Telegraph that crimes committed in the $\mathrm{BiH}$ uprising were not the same as in Syria, 15 years earlier. ${ }^{82}$ They were more critical in comparison to other articles regarding The Times correspondent from Odessa when they published his information about the vali who asked for new troops and advised to declare a holy war, and that the crimes committed by Muslims in Bosnia, both military and civilians, were destroying all hope of pacification; the editor commented that The Times correspondent always had a hostile attitude towards the Turkish government. ${ }^{83}$

The narrative on mutual slaughter of Christians and Muslims in Bosnia, especially on the preparations for a massive slaughter of Christians in places that had not been directly involved in the uprising, created a more open image on the necessity of an international military (humanitarian) intervention as the only efficient means against the disaster in Bosnia and Herzegovina and the long-term protection of the European peace. In that sense, a paradigmatic sentence from The Times is worth mentioning: "Nothing but a foreign Army of occupation can save Herzegovina from the risk of a catastrophe" ${ }^{84}$ In that sense, the attitude that the Ottoman Empire was completely unable to quash the uprising, with addition that the local Muslims, as a kind of a response to the uprising, were preparing a massive onslaught of the peaceful Christian population that had not taken up arms, kept appearing. Turkish commanders now appeared as the only saviours of Christians, since they were aware that the repetition of the Syrian crimes would mean an end of the Ottoman rule in Europe. ${ }^{85}$ Although no serious evidence existed on the

${ }^{80}$ The Pall Mall Gazette published a telegram previously published by the Daily News that "Perpetration of atrocities is increasing on both sides" Pall Mall Gazette, August 27, 1875, 5. They also published articles from The Spectator that Austrian newspapers were full of reports about "fearful atrocities on both sides". The Pall Mall Gazette, September 11, 1876, 7.

${ }^{81}$ Information was passed from Vienna of crimes committed by the rebels over their Muslim neighbours, and also of the rebels massacring Christians who did not want to join them in the uprising (with mentioning concrete instances for both). The Pall Mall Gazette, April 10, $1876,7$.

82 The Pall Mall Gazette, November 20, 1875, 2.

${ }^{83}$ This same report from Odessa was published in The Times, but without any editorial hedge or comment. The Pall Mall Gazette, April 10, 1876, 7.

${ }^{84}$ The Times, November 19, 1875, 9.

${ }^{85}$ Ibid. 
preparations for the onslaught of Christians, and notwithstanding the fact that it had never occurred, this narrative must have had a strong echo in the English public, especially considering the strong Christian solidarity of the English people.

The narrative of the onslaught emphasises the barbaric nature of the Ottoman society, as well as the Ottoman Muslims and Christians. In a discussion about a possible solution to the Bosnian issue after the uprising in Herzegovina, including the impossibility of providing self-governance to the local Christian population, fear of the Ottoman government that such a step would only increase the desire for independence was expressed. An obstacle to such a solution and any other that would not come from the West (the humanitarian intervention) was seen in the barbaric character of the Ottoman system and the Ottoman society. ${ }^{86}$ "Bulgarians, Bosnians and other Slavs in Turkey are not Italians or Greeks; they are people deeply enrooted in barbarism." 87 The correspondent from Pera was of the opinion that a full equality could not be achieved in the Ottoman Empire that was based on inequality, hence, he was convinced that it was easier to destroy the state than to change its organism. He did not see a way in which the sultan could practically implement reforms and equalise Christians and Muslims, and find a way to place Muslims and Christians to the same military barracks or joint councils. ${ }^{88}$ On the other hand, according to him, as well as according to The Times editor, not even the autonomous Balkan Christian principalities (Serbia and Montenegro) presented a better treatment of Muslims than the Ottoman state and the Ottoman Muslims towards Christians; rather, Muslims had even disappeared from those areas. ${ }^{89}$ The Times correspondent from Pera expressed fear that the same thing would happen with the numerous Slavic Muslim communities in Bosnia and Herzegovina and in Bulgaria, if Christians assumed authority in those parts of the Balkans. In this scenario too, the main culprit was the Ottoman system which had enabled a centuries-long oppression of Christians by their same-blooded Muslim brothers. According to the correspondent, it was difficult to find a solution to the Eastern Question that could happen without a massive onslaught or a wholescale robbery

\footnotetext{
${ }^{86}$ The Times correspondent from Pera stated opinion about barbarism as the essence of the Ottoman Turks. He stated that Turks had come to the Balkans as conquerors who established the authority by mass murder and persecution. The Times, December $11,1875,8$.

${ }^{87}$ From The Times correspondent from Pera. The Times, November 30, 1875, 6.

${ }^{88}$ Ibid.

${ }^{89}$ From The Times correspondent from Pera. The Times, November 30, 1875, 6. In considering the position of Muslims in case Bosnia stayed without a direct Ottoman rule, in a discussion about the uprising in Herzegovina and Bosnia, The Times editor warned against the fate of Muslims in Serbia from which, as he stated, Muslims had to be deported in order to be saved from massacres. "Practically the Mussulman population had to be removed from Servia to save it from massacre". The Times, August 27, 1875, 9.
} 
and forceful deportation of all Muslims. ${ }^{90}$ His deliberations, characterised by the spirit of orientalism and balkanism, inclined towards the proposal of a humanitarian intervention of major powers. More precisely, he proposed to divide Bosnia and Herzegovina (as he stated, why not even Bulgaria) between Russia and Austria, or to occupy the area by one of the two powers, provided that the other agreed. ${ }^{91}$ As a hedge towards such a solution, we can see his fear that an international humanitarian intervention, in the very beginning, could signal Muslims to massacre Christians. ${ }^{92}$

In discussions that mentioned preparations of $\mathrm{BiH}$ Muslims to slaughter Christians, the Ottoman military commanders and civil servants appeared as positive actors, preventing the realisation of the local barbarians' intentions. Still, as is almost always emphasised, they were not guided by humane motifs, but by exclusively practical political reasons, i.e. fear that the repeated massacre of Christians in the Ottoman Empire, similar to that in Syria, would mean an end of the Ottoman rule. ${ }^{93}$ That was discussed in the British Parliament, where the opposition used the rumours about a possible massacre of Christians in Bosnia as an argument for criticism of the conservative government, in the sense that it was not conducting the right eastern politics. ${ }^{94}$ In a similar spirit, The Times special correspondent from Mostar reported on 30 October 1875 that, five days prior to the arrival of the consular mission to Mostar, a prisoner had been hanged in front of a mosque in order to "pacify the bashibazouk that for six days prior to the event had planned to perpetrate a massive manslaughter of the Mostar Christians." ${ }^{95}$ It appears that denials by the Ottoman provincial and local authorities of the existence of any

90 "There are, perhaps, four million of them, exclusive of Constantinople, and it is difficult to conceive any solution of the Eastern Question that may effected without the general massacre or the whole-sale plunder and forcible expulsion of them all." From The Times correspondent from Pera. The Times, November 30, 1875, 6.

${ }^{91}$ From The Times correspondent from Pera. The Times, November 30, 1875, 6.

${ }^{92}$ In March the following year, the same correspondent, in a discussion entitled "Turkey", quoted an opinion by the Russian General Ignjatijev about a considerable possibility of Bosnian Muslims massacring Christians. "...the mere report of one Austrian or other Christian soldier marching across the frontier could not fail to be a signal for a general massacre of the Christians by the Bosnian Mahomedans." From The Times correspondent from Pera. The Times, March 22, 1876 , 10.

${ }^{93}$ Reflecting upon the uprising and the current situation, the editor stated that the sultan, under the patronage of major powers, was aware of the fact that another massacre committed as an expression of Muslim fanaticism, like the one in Syria, would mean the end of the Ottoman Empire. The Times, December 13, 1875, 9.

${ }^{94} \mathrm{Mr}$. Baxter emphasised during a parliamentary debate that he had for long had a feeling that the British politics towards the Ottoman empire was dissatisfactory and that it should be made public. He added: "I have been told by many that a massacre is expected by fanaticised Muslims (in Bosnia and Herzegovina) over Christians, similar to the one in Damascus. The Times, June 19, 1876, 9.

${ }^{95}$ The Times, November 11, 1875, 8. 
preparations for the massacre of Christians in Bosnia and Herzegovina failed to convince the English public, regardless of the fact that they were published by The Times. ${ }^{96}$

In editorial discussions, articles from correspondents and by publishing news and opinions from other sources, the Daily News followed the footsteps of The Times regarding the construction of an image of a massacre of Christians in Bosnia. Muslims of Bosnia and Herzegovina in some places that were not affected by the uprising, had been "undoubtedly" preparing the slaughter of Christians, ${ }^{97}$ and the only salvation for the Christians was the awareness of the Ottoman military and civil representatives that such a slaughter would unite the Christian powers in the Eastern Question, which would result in the disappearance of the Ottoman Empire. The awareness of Muslims that the slaughter of Christians would cause the European military (humanitarian) intervention ${ }^{98}$ was also mentioned. Mentioning of mosques as places where Muslims planned the massacre of Christians ${ }^{99}$ strengthened the religious discourse and anti-Muslim sentiment among the English public, which could function also as additional argumentation for the construction of the image of the division along the religious and civilizational line.

The Pall Mall Gazette also tackled the possible humanitarian intervention by publishing the opinions of individuals and other papers about it, although the editor of the newspaper was not convinced that a foreign military intervention would solve

${ }^{96}$ Upon hearing rumours that reached Constantinople that a massive massacre of Christians was being prepared, the Ottoman officials issued a proclamation denying that information. The Times, November 5, 1875, 5.

${ }^{97}$ The Daily News correspondent from Vienna stated that the information arrived from different sources that Muslims would undoubtedly slaughter Christians in southern Bosnia. Daily News, November 13, 1875, 5. In relation to the Massacre of Thessalonica, the Daily News published an opinion from The Times from Paris that this was not an isolated case, but rather that Muslims in Bosnia and Herzegovina too had several times assembled to prepare the onslaught of Christians. Daily News, May 12, 1876, 5. The Daily News' permanent correspondent from Vienna mentioned the possibility of an onslaught of Christians in Bosnia and Herzegovina. Daily News, April 27, 1876,5 .

${ }^{98}$ The Daily News editor, in a discussion about the events in Herzegovina, emphasised that, regardless of many reports about the possible slaughter of Christians by Bosnian Muslims, such an event would not take place (although there would be individual crimes), for "Bosnian Muslims know well that such an event would probably cause such sentiment in Europe that it would inevitably result in a (humanitarian) military intervention.” Daily News, November 17, 1875, 4.

${ }^{99}$ The Daily News mentioned the writing of the Nord, a newspaper from Brussels, on the basis of a telegram from Dubrovnik, that Muslims of Herzegovina were bitter and that secret meetings were held in mosques in Mostar, Buna and in other places in order to execute preparations for the massive onslaught of Christians. The Daily News provided a multi-perspective remark that the allegations had not been confirmed by other sources. Daily News, November 8, 1875, 5 . 
the issue of violence, including the onslaught of Christians. ${ }^{100}$ In that spirit, The Pall Mall Gazette editor presented an opinion in November 1875 that conditions for solving the Eastern Question, which was again open by the Herzegovina uprising the financial debacle of Constantinople, had not been met. He argumented his attitude by stating that the European powers had different interests regarding the Eastern Question, as well as by expressing fear over producing a negative effect on the sultan by pressuring him too much. The Pall Mall Gazette was more careful about the "rumours" on the Muslim conspiracy to massacre all Christians in Bosnia and Herzegovina, so the editor, on 18 November 1875, emphasised: "if there is any truth in those rumours - it is exaggerated" ${ }^{101}$ The newspaper emphasised exaggerations that appeared in the descriptions of violence and possible massacre of Christians in other newspapers, ${ }^{102}$ even brought into question the classification of crimes mentioned in other newspapers. Apart from that, he also emphasised the repeated acts of violence and crimes perpetrated by the rebels over the local Muslims and Christians who did not share their position. ${ }^{103}$ At the same time, The Pall Mall Gazette created an image of religious hatred and an uncontrolled fanaticism of the sultan's Muslim subjects in Bosnia and Herzegovina and other European provinces. ${ }^{104}$ On the other hand, when he considered that there was some truth

${ }^{100}$ See The Pall Mall Gazette's editorial reaction to E. A. Freeman's opinion on the necessity of a swift European military intervention for the sake of the European peace and humanity. The Pall Mall Gazette, December 15, 1875, 3.

101 The Pall Mall Gazette, November 18, 1875, 1.

102 The editor critically examined the Paris dispatch published in the Daily News that a massacre of Christians took place in Prijedor (the author wrote "Piedor"). He emphasised that, notwithstanding the fact that the number of victims had been reduced to 100 from the initial 3,000, it was still a severe crime, "but even thin leaves the gravity of the incident virtually unaffected". In the end, he presented The Pall Mall Gazette readers an image of the incident. A certain number of young Christians had prepared to leave the town. They were attacked by Muslims, killing about a hundred of them, including many women and children. Among them was also a priest. Selim Pasha, "according to the Turkish custom" arrived on time to be late. A number of Muslims was arrested in relation to this incident, but the author of the dispatch emphasised that considering those were the people of same faith, chances of them being punished were slim. The Pall Mall Gazette, May 20, 1876, 1.

${ }^{103}$ They published the writing of the Neue Freie Presse newspaper about the acts of "outrage" over Muslims of Bosanska Dubica. They mentioned a murder of a bey and hanging of a Christian woman from the village Kosuz, because she had colluded with Turks. The Pall Mall Gazette. 8 September 1875,5 .

104 "... but it is clear enough that the outbreak (if it really happened) was of religious origin, and that the uncontrollable fanatism of the Mahommedan subjects of the Porte has impaled them to an act of violence, far more serious in its import, because indicating a more general popular excitement than the murder of the consuls at Salonica." The Pall Mall Gazette, May 20, 1876, 1. The Pall Mall Gazette editor, in a discussion about the situation in the Ottoman Empire, reflecting on the violence in Thessalonica, concluded that such violence could take place anywhere. The Pall Mall Gazette, May 9, 1876, 1. 
about the information about a massacre, The Pall Mall Gazette published them and the editor used the information to argument his discussions. ${ }^{105}$

The more careful opinion of The Pall Mall Gazette editor on the possible massacre of Christians was not an obstacle for this paper to pass opposing information and opinions, for the purpose of as objective informing as possible, related to the preparations for the massacre of Christians and other violence in Bosnia and Herzegovina, ${ }^{106}$ as well as related to the necessity of Austrian or some other foreign occupation in order to protect Christians from the massacre. ${ }^{107}$

Observed as a whole, a direct link between the cruel crimes, a possible onslaught of Christians and other kinds of violence on the one hand, and a military humanitarian intervention in Bosnia and Herzegovina in the period of the uprising on the other, was most strongly advocated by The Times. This newspaper created an image of the necessity of such a development if peace was to be preserved in Europe and further bloodshed and murder of the innocent prevented from happening further. The Times emphasised that the major powers could not escape their obligation which was the consequence of their strength. The example of the massacre of Christians in Syria was mentioned in the sense that the Paris Agreement did not prevent the French Government to deploy troops, or a foreign committee to investigate the incidents. From this approach, The Times editor concluded in the early 1876 that a direct

${ }^{105}$ On the occasion of a parliamentary discussion on the uprising in Herzegovina, the editor presented an opinion that the obstacle to the implementation of reforms in Herzegovina and Bosnia was the massacre in Popovo polje over Christian returnees. The problem was also that the perpetrators had not been punished, regardless of the pressure from the British Ambassador Elliot in Constantinople. The Pall Mall Gazette editor was of the opinion that the punishments lacked due to fear of an outrage among the local Muslims. The Pall Mall Gazette, April 21, 1876, 4.

106 They published a text from The Times correspondent from Mostar about the violence and murders of Christians (11 November 1875), including the murder of a 13-year-old boy (the killer was not punished), as well as about planning of “... a general massacre of the Christians of Mostar.") The massacre was prevented by the persistence of a wise Muslim aga who had warned that the massacre would result in the Austrian occupation of Bosnia and Herzegovina. The Pall Mall Gazette November 11, 1875, 8. In August 1875, they published an article from The Spectator that every Muslim was entitled to insult or implement violence over any Christian neighbour. Such a privilege had produced worse crimes in the country than those perpetrated by soldiers, who were entitled to slaughter any man or woman that provided refuge to the rebels. The Pall Mall Gazette, August 14, 1875, 3.

${ }^{107}$ On 5 January 1876, The Pall Mall Gazette published excerpts from The Times' special correspondent in Dubrovnik about the situation of Christians in Herzegovina. The correspondent emphasised that the opinion of all who had been acquainted with the situation was that the Austrian occupation of Bosnia and Herzegovina, for political and humane reasons, was the only true step, and the same applied to all other districts that would fall into rebellion in the period of intervention. He added that if the waiting period was long, all European provinces would request the occupation, including Bulgaria and Crete. The Pall Mall gazette, January 5, $1876,7$. 
international (military) engagement had been necessary. ${ }^{108}$ In the process of selecting a state best suited for the intervention, The Times favoured the Austro-Hungarian Monarchy for a number of reasons, since it was a bordering state that had most interests there.

\section{Conclusion}

The anti-Turkish atrocity agitation in England regarding the Turkish crimes in Bulgaria, had created a clear political demand towards the representatives of the British foreign policy - independence (autonomy) of the administration of the European provinces of the Ottoman Empire, including Bosnia and Herzegovina, and, within it, a less defined demand for the persecution of Turks from Europe: "outgoing Turks, beg and baggage". The anti-Turkish agitation discourse, and, consequently, its political demand, were followed by, strengthened, initiated and shaped in the influential newspapers. In the first stage of the most serious interest of the British press into the Bosnian Question and the BiH uprising, there was not as strongly repeated political message that could constitute a dominant opinion of the public. This phase of the creation of a discourse about the Ottoman (Muslim) government in Bosnia and Herzegovina and the necessary liberation from the Balkan Christian subjects of the Ottoman sultan could be marked as the preparatory phase, characterised by the strengthening of the British public for the events in Bosnia and Herzegovina, a gradual construction (upgrading) of the image of the Turkish guilt for jeopardising the European peace, as well as for jeopardising the primary British interests. Causes of the uprising were sought in the essential character of the Ottoman Muslim country that had failed to secure the legal equality of the population in the Balkan provinces. Christians in Bosnia and Herzegovina, as well as Christians of other Balkan provinces, perceived the Ottoman rule as unjust, as the rule supporting the unified violence of the provincial and local authority representatives and upper classes of the local Muslim community against them. They and those who supported them (the Ottoman state) were the ones who had been oppressing them systematically and continually, and, from the beginning of the uprising, they committed vicious crimes and were preparing the massive onslaught of Christians. However, in this phase, such an image had not been strong enough to construct a predominant and a generally accepted discourse, while some texts and some newspapers were still observing all the elements of the socio-political relations through a multi-perspective and critical dimension. Russia, with its political pretensions towards the Ottoman Empire, as well as the disturbance of the balance between the great powers, were still the desired culprits that could be blamed for causing the unrest and for jeopardising peace. And it

${ }^{108}$ The Times, January 17, 1876, 9. 
did not matter whether that was achieved through the state apparatus, or Slavophiles, or with the help of Serbia and Montenegro. In a lesser extent, as possible culprits, there were Germany and Austro-Hungary. In such an approach, The Pall Mall Gazette was most prominent, since it denied any philanthropic motifs of these powers, especially Russia. In that way, morality in conducting the politics did not have a praiseworthy background. On the other hand, as expected, the Daily News took an opposite stance to The Pall Mall Gazette, constructing more strongly the anti-Turkish discourse. Although The Times, in accordance with its determination to inform, not to impose opinions to the public, mostly passed someone else's information and opinions, the editor selected the information and texts for publishing and, through his own occasional observations, and especially by the fact that his special correspondents observed those issues, he significantly contributed the creation of the anti-Ottoman discourse. It should be emphasised that texts published in The Times were borrowed by the local newspapers, which also multiplied their influence. Also, one may say that, apart from the occasional different examples, for example, the responsibility of Austria for a certain humanitarian intervention, the care for the previously-defined British primary interests of preserving the status-quo as the best solution dominated. A strong proposal that would change the situation and mark the inherited British politics in the Eastern Question as wrong and immoral did not appear at the time. The published observations of Edward A. Freeman were not strong enough to change the situation described by the last remark.

\section{Bibliography}

\section{Sources}

\section{Unpublished sources}

\subsection{National Archives of the United Kingdom, Foreign Office Archives, London}

F.O. $195 / 1101$

\subsection{British Newspaper Archive, London}

Daily News

The Pall Mall Gazette

\subsection{Newspapers Archive, USA}

\section{Daily News}

The Pall Mall Gazette

The Times 


\section{Published Sources}

Turkey, Correspondence respecting Affairs in Turkey, Vol. 1, London: Harrison and Sons, 1876.

Turkey, Correspondence respecting Affairs in Turkey, Vol. 2, London: Harrison and Sons, 1876.

Turkey, Correspondence respecting Affairs in Turkey, Vol. 3, London: Harrison and Sons, 1877.

\section{Travelogues}

Arbuthnot, L. G. 1969, Hezegovina, or Omer Pach and the Christian Rebbels, with a breaf Account of Servia, its Social. Political, and Financial Condition. London: Longman, Green, Longman, Roberts, Green, \& Green.

\section{Books and articles}

Eldem, E. 2011, The Ottoman Empire and Orientalism: An Awkward Relationship, in: Vatin, J. C./Pouillon, F. (eds.), After Orientalism: Critical Perspectives on Western Agency and Eastern Re-appropriations, Leiden: Brill, 89-102.

Gürpinar, D. 2012, The Rise and Fall of Turcophilism in Nineteenth Century British Discourses: Visions of the Turk, 'Young' and 'Old', British Journal of Middle Eastern Studies, Vol. 39, No. 3, Coventry: BRISMES, 347-372.

Iseminger, G. L. 1968, Old Turkish hands: The British Levantian Consuls, 18561876, Middle East Journal, Vol. 22, No. 3, Washington: Middle East Institute 297-316.

Jakšić, G. 1955, Bosna i Hercegovina na Berlinskom kongresu, Beograd: Naučna knjiga.

Kasumović, A./Radušić, E. 2017, Zaljubljeni u plijen. Austrougarska uprava u Bosni i Hercegovini 1878-1918, In: Sijarić M. (ed.), Između dvije imperije. Bosna i Hercegovine na fotografijama Františeka Topiča 1885-1919, Sarajevo: Zemaljski muzej Bosne i Hercegovine, 187-205.

Perkins, J. A. 2014, British liberalism and the Balkans, c. 18751925, (Phd Dissertation), London: Birkbeck, University of London.

Radušić, E. 2013, Bosna i Hercegovina u britanskoj politici od 1857. do 1878. godine, Sarajevo: Institut za istoriju.

Radušić, E. 2014, Suživot ili mržnja i podjela (Britanci o bosanskom društvu potkraj osmanske vlasti), Almanah - Časopis za proučavanje, prezentaciju $i$ zaštitu kulturno-istorijske baštine Bošnjaka/Muslimana, 63-64, Podgorica: Udruženje "Almanah", 97-113. 
Rodogno, D. 2012, Against Massacre, Humanitarian Interventions in the Ottoman Empire, 1815-1914, The Emergence of a European Concept and International Practice, Princeton and Oxford: Princeton University Press.

Savic, A. 2008, Intimate Antagonists British Images of the Balkans, 1853-1914, (Phd Dissertation), Riverside: University of California.

Todorova, M. 1999, Imaginarni Balkan, Beograd: Biblioteka XX vek.

Whitehead, C. E. A. 2014, The Bulgarian Horrors: Culture and the International History of the Great Eastern Crisis. (Phd Dissertation), Vancouver: University of British Columbia. 